\title{
The Nexus Between Background Instructional Supervisors' Characteristics and Instructional Supervisors' Competences in Kenya
}

\author{
Dr Solomon Gitonga Mwaniki \\ School of Education, Mount Kenya University, P. O. Box, 342-01000, Thika, Kenya
}

\begin{abstract}
The concern for having instructional supervisors with requisite instructional supervision background characteristics in the education sector has always been recognized globally. The purpose of this study was to investigate the background instructional characteristics of instructional supervisors in Nairobi and Machakos Counties, Kenya. The objectives of the study were: to establish the professional qualifications of instructional supervisors, ascertain their years of service as instructional supervisors, establish positions held by QASOs prior to appointment as QASOs, and to assess QASOs' years of experience as teachers before appointment as QASOs. The study adopted ex post facto survey design and had a target population of 1481(N) persons which comprised of 365 school principal teachers, 17 SC-QASOs, 2 C-QASOs, 2 N-QASOs and 1095 HOD teachers. A sample of 460 (n-31\%) respondents comprising of teachers (110 Principal teachers\& 329 HOD teachers) and 21 QASOs were drawn from the target population. Purposive, stratified and simple random sampling were used to select the locale of the study and respondents used for the study. Data were collected using questionnaires and interview schedules. The major finding of this study was that instructional supervisors had requisite background characteristics in instructional supervision.
\end{abstract}

Keywords: Instructional supervisors, instructional supervision, Professional qualifications

DOI: $10.7176 / \mathrm{JEP} / 11-13-09$

Publication date:May $31^{\text {st }} 2020$

\section{Introduction}

It has been observed that for instructional supervisors to be effective, they need to exhibit major desirable instructional supervisory competences of conducting instructional supervision practices such as; knowledge about public relations, ability to lead by example, high integrity, and competence in teaching subjects or technical competences (Zachariah, 2013; Milcah, Chisikwa and Odwar, 2010). Stressing on the importance of the teachers instructional supervisors exhibiting desirable instructional supervisory competences, Kutsyuruba, (2003), Sergiovanni \& Starratt, (2007) and Zepeda, (2007) note that, the perceptions of teachers towards instructional supervisory competences of instructional supervisors depends largely on availability of supervisory choices based on teachers' instructional needs (technical competences), a harmonious teacher-supervisor relationship and as well as mutual trust, respect and collaboration among supervisees and supervisors. In this regard therefore effective instructional supervisory practices conducted by instructional supervisors in schools can be assessed using the yard stick of teachers' perceptions towards instructional supervisors' competences of conducting instructional supervision, how actual the instruction supervision is conducted in a school and whether or not it improves the teachers' instructional abilities to offer quality education.

\section{Literature review}

\subsection{Professional Qualifications of Instructional Supervisors}

According to Okoro (2004), education personnel with higher qualifications display more confidence in their workplace because higher qualifications enables them to perform better in the field than those with lower qualification. In this respect, higher qualifications than the basic minimum enable instructional supervisors to interpret policies governing education quality. However, studies by Mohammed \& Orodho (2014) and Ogandoh (2015) found that majority of the QASOs in the field did not only have the required academic qualifications but had relatively long periods of experience of being exposed to instructional supervision practices in various capacities in public schools. This meant that as much as QASOs had requisite exposure on issues related to instruction as exercised by teachers in schools and they lacked fundamental professional qualification upon which requisite exposure should have been grounded on.

In a study by Chisikwa and Odwar (2010) it was revealed that instructional supervisors felt that they had average competences in respect to skills of: human relations, knowledge of the subject, supervision approach and report writing. Indeed, Kayaoglu, (2012) had found that external educational instructional supervisory process did not add any pedagogical or professional value to teachers, mainly because of the manner in which the external instructional supervisory process was conducted in learning institutions. It has be established teachers always preferred to be supervised by instructional supervisors who are professionally qualified with knowledge and skills 
of supervision, and who exhibited friendly approaches in instructional supervision exercise (Tesfaw and Hofman, 2012).

The deficiency of essential pragmatic competences creates the perception that instructional supervisors have partial competences in instructional supervision; it is indicative that instructional supervisors need to improve their professional instructional competences to ultimately be more effective in their work of instructional supervision.

\subsection{Experience of the instructional supervisors}

In the European Union member countries; the Education Quality Assessors must have a certain number of years of professional experience in a school other than just having a teaching qualification and in a management position (European Commission/EACEA/Eurydice, 2015). This means that effective instructional supervision in schools can only be entrusted to experienced instructional supervisors. In a study by Kamindo (2008) it was established that the actual instructional supervision performance of instructional supervisors did not meet the teacher's expectations as much as instructional supervisors thought otherwise. Similarly, an earlier study by Govinda and Tapan (1999) it had been revealed that instructional supervision as a means of improving quality education in schools focused on teachers and their performance with little regards to supporting the teachers' competences. These scenario negates the basis rudiments of instructional supervisors progressively addressing teachers' instructional challenges.

Kimathi (2013) who found that most instructional supervisors did not have sufficient technical knowledge in their areas of specialization, consequently indicating lack of experience in instructional supervision, and as Naci (2012) had established, conducting of effective instructional supervision required instructional supervisors to have both the technical skills knowledge in their respective subject areas and experience of having exercised the numerous technical skills knowledge in the field in empowering the teachers in different contexts to cater for learners with varied learning styles (Desimone, 2009 \& Koehler, 2011). Other studies by Griffin (1994) and Zachariah (2013) found that most instructional supervisors did not exhibit sufficient technical competences mainly due to lack of experience and therefore could hardly provide expert knowledge and guidance to teachers, meaning that the quality of education can be compromised due to lack of requisite experience by the instructional supervisors.

\section{Purpose and objectives of the study}

The purpose of this study was to establish the extent to which instructional supervisors have requisite background instructional supervision characteristics. The objectives of the study were;

a) Establish the professional qualifications of instructional supervisors

b) Ascertain years of service of the instructional supervisors

c) Establish Positions Held by QASOs Prior to Appointment as QASOs

d) Assess QASOs' Years of Experience as Teachers before Appointment as QASOs

\section{Research design and methodology}

This study used ex post facto survey design, combining both qualitative and quantitative approaches in data collection and analysis techniques to achieve the objectives of the study. This design was appropriate for the study because the researcher was interested in determining the status quo with regard to the background characteristics of instructional supervisors in public secondary schools. The target population of this study was $1481(\mathrm{~N})$ instructional supervisors; 365 school principal teachers, 17 SC-QASOs, 2 C-QASOs, 2 N-QASOs and 1095 HOD teachers; from which a sample of 460 (n-31\%) respondents comprising of teachers (110 Principal teachers\& 329 HOD teachers) and 21 QASOs were drawn. Purposive sampling was used to select the two counties where the study was conducted while stratified and simple random sampling was used to select the schools where the study was conducted. Respondents for the study were selected purposively because of their relevancy to the study. Data were collected using questionnaires and interview schedules.

\section{Research findings and discussion}

\subsection{Professional Qualifications of Instructional Supervisors}

The study sought to establish the academic qualifications of the various respondent groups. The results are reported in table 1.0 
Table 1.0: Professional Qualifications of Principals, HOD teachers and QASOs

\begin{tabular}{lllllll}
\hline \multirow{2}{*}{ Academic Qualification } & \multicolumn{3}{c}{ Principals } & \multicolumn{1}{c}{ HOD teachers } & \multicolumn{2}{c}{ QASOs } \\
\cline { 2 - 7 } & $\mathbf{N}$ & \multicolumn{1}{c}{$\mathbf{\%}$} & $\mathbf{N}$ & $\mathbf{\%}$ & $\mathbf{N}$ & $\mathbf{\%}$ \\
\hline Diploma in Education & 5 & 4.6 & 32 & 10.9 & - & - \\
B. Education & 59 & 54.1 & 190 & 64.8 & 3 & 17.6 \\
PGDE & 3 & 2.8 & 20 & 6.8 & - & \\
M. Education & 37 & 33.9 & 33 & 11.3 & 12 & 70.6 \\
PhD in Education & 1 & 0.9 & 1 & 0.3 & 1 & 5.9 \\
Others (BSC, BA, MBA) & 4 & 3.7 & 17 & 5.8 & 1 & 5.9 \\
\hline Total & $\mathbf{1 0 9}$ & $\mathbf{1 0 0 . 0}$ & $\mathbf{2 9 3}$ & $\mathbf{1 0 0 . 0}$ & $\mathbf{1 7}$ & $\mathbf{1 0 0 . 0}$ \\
\hline
\end{tabular}

Table 1.0 reveals that majority of school principal teachers $59(54.1 \%)$ and heads of department teachers $190(64.8 \%)$ had bachelor of education degree as their highest level of academic qualification followed by $37(33.9 \%)$ of school principal teachers and 33(11.3\%) of heads of department teachers who had masters of education. Majority 12(70.6\%) of QASOs had masters of education as their highest level of education followed by $3(17.6 \%)$ who had bachelor of education degree. Only $1(0.9 \%)$ of the principals, $1(0.3 \%)$ of the heads of department teachers and 1(5.9\%) of the QASOs had PhD level of education. This indicates that the bulk of the respondents for this study had either bachelors or masters' degree as the highest level of academic qualification.

Considering that the minimum academic qualification required by Teachers Service Commission (TSC) and Public Service Commission (PSC) for one to be employed as a teacher and QASOs is a Diploma in education and bachelors' in education respectively, then all the respondents for this study had met the basic academic qualifications to occupy the positions they were in at the time of conducting the study. According to Okoro (2004), education personnel with higher qualifications display more confidence in their workplace because higher qualifications enables them to perform better in the field than those with lower qualification. In this respect, because the majority of the respondents had higher qualifications than the basic minimum, this implied that they understood and were able to interpret policies governing education quality. This meant that data collected from these respondents was reliable and reflected the situation on the ground.

\subsection{Instructional Supervisors' Experience}

To establish the experience, the respondents had in discharging their responsibilities, the researcher sought to find out the years of service the various respondents had in their current positions. The results are illustrated in Figure 1.0

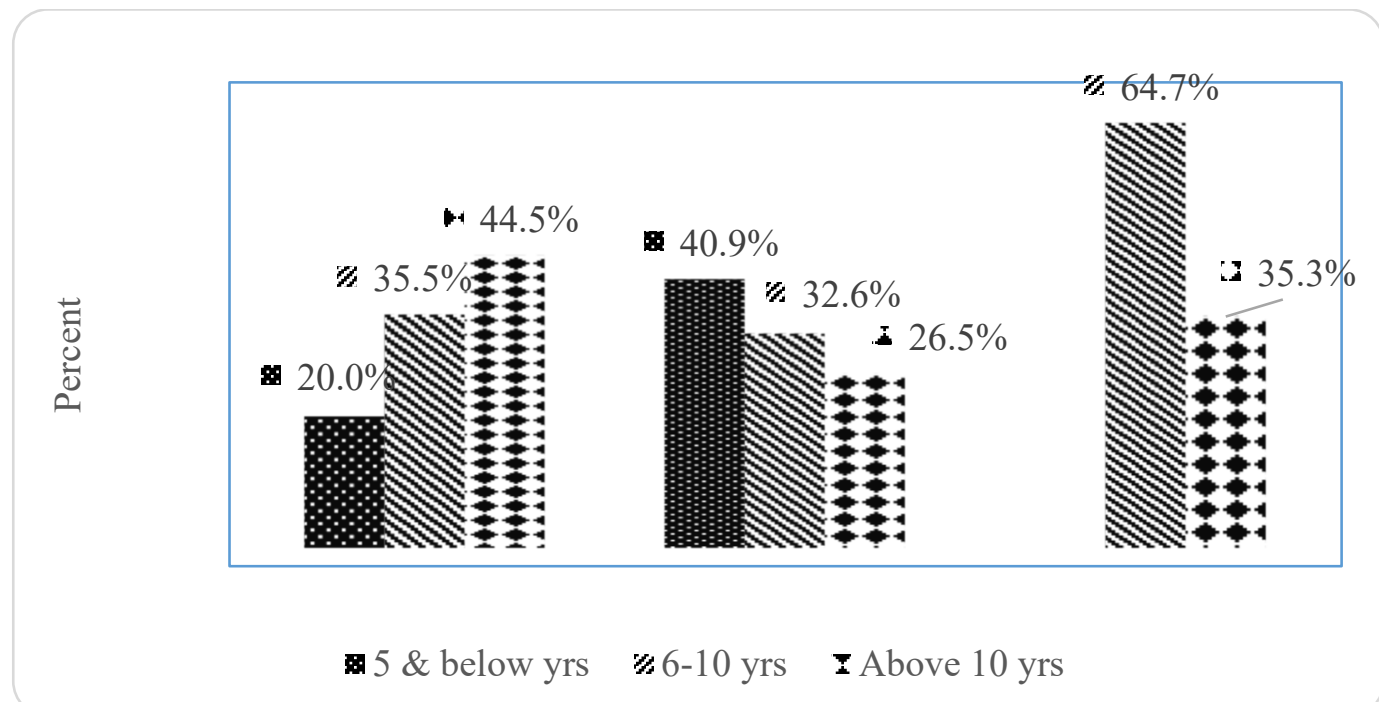

Figure 1.0: Instructional Supervisors Experience as Principals, HOD teachers or QASOs

From figure 1.0, it is clear that most 49(44.5\%) of principal teachers and most $120(40.9 \%)$ of HOD teachers had working experience of above 10 years and 5years and below years respectively. It is only a small percentage $22(20.0 \%)$ of principal teachers who had experience of 5 years and below. Further, majority $11(64.7 \%)$ of QASOs reported that they had been in that position for 6-10 years while the rest 6(35.3\%) of the QASOs said that they had held the position for more than ten years.

Given that experience is a major factor contributing to the effectiveness of an employee performance, it's clear that the respondents of this study had the requisite professional experiences and therefore it was envisaged that they could provide credible supervision of the curriculum. This scenario is similar to what is found in the European Union member countries; where the Education Quality Assessors must have a certain number of years 
of professional experience in a school other than just having a teaching qualification and in a management position (European Commission/EACEA/Eurydice, 2015).

\subsection{Position Held by QASOs Prior to Appointment as QASOs}

In respect to QASOs, this study sought to find out the substantive positions held by QASOs prior to appointment as QASOs. This is shown in table 1.2

Table 1.2: Position Held by QASOs Prior to Appointment as QASOs

\begin{tabular}{lcc}
\hline Position & $\mathbf{N}$ & $\mathbf{\%}$ \\
\hline Subject teacher & 1 & 5.9 \\
Head of Subject & 6 & 35.3 \\
HoD & 9 & 52.9 \\
Deputy head teacher in Secondary School & 1 & 5.9 \\
\hline Total & $\mathbf{1 7}$ & $\mathbf{1 0 0 . 0}$ \\
\hline
\end{tabular}

Table 1.2 shows that majority, 9(52.9\%) followed by 6(35.3\%) of the QASOs were HOD teachers and Heads of Subjects in their areas of specialization respectively before appointment as QASOs. This implies that most of the QASOs in the field and were used in this study; had risen up the instructional supervision ladder, have experiences of being instructionally supervised and know whether instructional supervision adds value to quality education provision in schools. This scenario is similar to what is found in the European Union member countries; where the Education Quality Assessors must have a teaching qualification and a certain number of years of professional experience in a school, as a teacher or in a management position (European Commission/EACEA/Eurydice, 2015).

\subsection{QASOs' Years of Experience as Teachers before Appointment as QASOs}

The researcher further sought to establish the number of years that QASOs had actively spent as classroom teachers in their areas of specialization before appointment as QASOs. The responses are shown in Figure 1.2

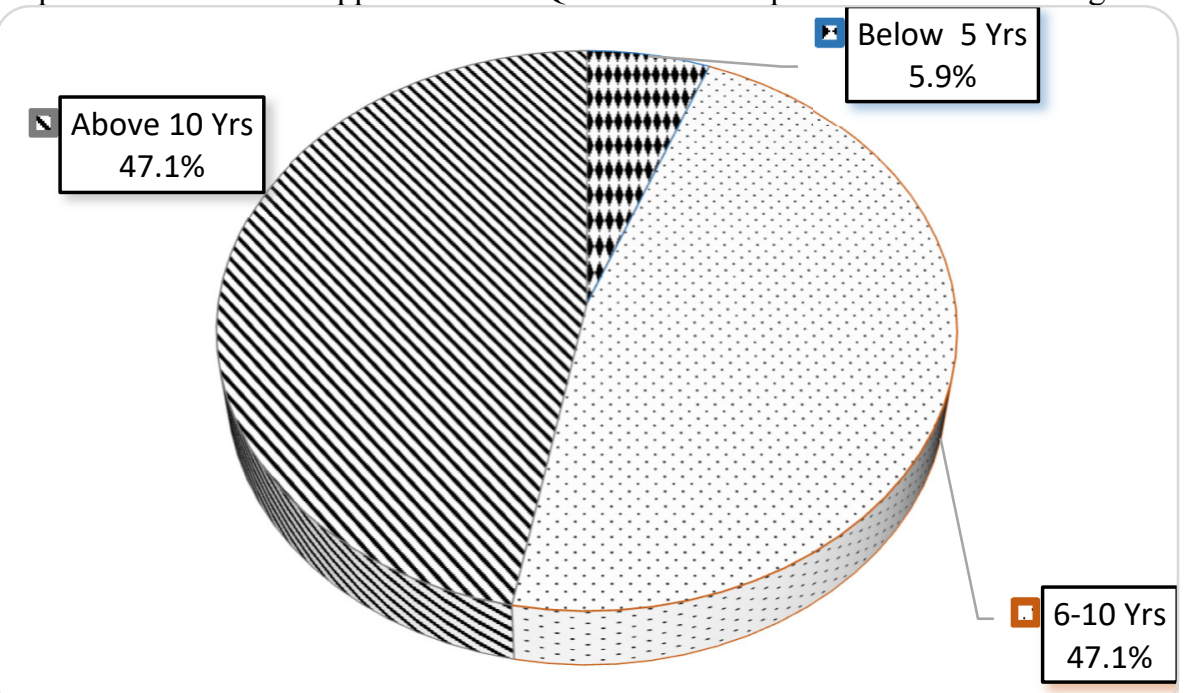

Figure 1.2: QASOs' Years of Experience as Teachers before Appointment as QASOs

Figure 1.2 indicates that an equal majority, 8(47.1\%) of the QASOs reported that they had been actively teaching in their area of specialization in secondary schools for more than ten years and between 6-10 years before their appointment as QASOs. Only one 1(5.9\%) QASOs said that he/she had actively taught in secondary school for 5 years and below. Generally, therefore majority of the QASOs used in this study had progressively advanced from classroom teachers, heads of subjects and HOD teachers before being appointed as QASOs. This would imply that they have accumulated requisite experiences on issues of instructional supervision.

These findings agree with Mohammed \& Orodho (2014) and Ogandoh (2015) who found that majority of the QASOs in the field did not only have the required academic qualifications but had relatively long periods of experience of being exposed to instructional supervision practices in various capacities in public schools. Consequently, this meant that they had requisite exposure on issues related to instruction as exercised by teachers in schools and they are well placed to be proactive agents of positively transforming the status quo of instruction in schools. 


\subsection{Conclusions and recommendations}

5.1 Conclusions

The following are the conclusions of this study;

a) It was established that the instructional supervisors in public secondary schools had sufficient professional qualifications as instructional supervisors

a) The study ascertained that instructional supervisors had adequate years of service as instructional supervisors in their respective areas of jurisdictions.

b) It was established that QASOs occupied requisite instructional supervisory positions prior to appointment as QASOs

c) It was found out that QASOs' had relevant sufficient experience as teachers before appointment as QASOs

\subsection{Recommendations}

This study recommends that appointment instructional supervisors should continuously be based on sufficient professional qualifications in instructional supervision, Further, instructional supervisors should be exposed to varied instructional supervision environments to accumulate requisite instructional supervision experience which becomes hardy during instructional supervision.

\section{References}

Desimone, L. M., Smith, T. M., \& Frisvold, D. E. (2009). Survey measures of classroom instruction: Comparing students and teachers' reports. Educational Policy Online First, dol: 10.

European Commission/EACEA/Eurydice, 2015. Assuring Quality in Education: Policies and Approaches to School Evaluation in Europe. Eurydice Report. Luxembourg: Publications Office of the European Union

Griffin, G. (1994) School Mastery, Straight talk about boarding school management in Kenya. Nairobi: Lectern Publishers

Kamindo, C. (2008). Instructional supervision in an era of change: policy and practice in primary education in Kenya, Unpublished PhD Thesis: Durham University, United Kingdom.

Kayaoglu,M.N. (2012). Dictating or facilitating: The supervisory process of language teachers. Australian Journal of Teacher Education, 37(10), 103-117. https://doi.org/10.1422/ajte.2012v37n10.4

Kimathi, G.C. (2013) Challenges facing Quality Assurance and Standards Officers' in supervising implementation of secondary School curriculum in Tigania Central Division of Tigania East District, Kenya, unpublished Med. Project: Mount Kenya University.

Kutsyuruba, B. (2003). Instructional supervision: Perceptions of Canadian and Ukrainian beginning high-school teachers (Master's thesis). Saskatoon: University of Saskatchewan. [online] http://library2.usask.ca/theses

Milcah, Chisikwa and Odwar (2010) Perception of quality assurance and standards officers about their competence: Implications for training Educational Research Vol. 1(4) pp. 112-117 May 2010 Available online http://www. interesjournals.org/ER Copyright (C2010 International Research Journals

Mohammed, M.M, Orodho, J. (2014) Effectiveness of Quality Assurance and Standards Officers' School Supervisory Roles in Enhancing Students' Academic Performance in National Examinations in Nakuru District, Kenya. Journal of Education and Practice.Vol.5, No.16, 2014

Naci, M.K., (2012). Dictating or Facilitating: The Supervisory Process for Language Teachers. Australian Journal of Teacher Education, (37)10. October 2012, 103-117

Okoro, N. J. (2004) The Role of Sex in Education Achievement. Journal of eachers

Perspective. Benin:Vol. 4(2) pp. 12-14.

Ogandoh, G.L., (2015). Teachers' Perception on the Role of Quality Assurance and Standards Officers in Public Secondary Schools in Busia Sub-County. Unpublished M.Ed. Thesis. Kenyatta University

Sergiovanni, T. \& Starratt, R. (2007). Supervision: A redefinition. (8th ed.). New York: McGraw-Hil

Tesfaw, T. \& Hofman, R. (2012). Instructional Supervision and Its Relationship with Professional Development: Perception of Private and Government Secondary Schools in Addis Ababa. Unpublished Med Thesis, University of Addis Ababa.

Zachariah, W.O. (2013). Skills and attributes of instructional supervisors:

Experience from Kenya. Academic Journals Vol. 8(24), pp. 2270-2280, 23 December, 2013 DOI: 10.5897/ERR12.057ISSN 1990-3839 C 2013 http://www.academicjournals.org/ERR

Zepeda, S. J. (2007). Instructional supervision: Applying tools and concepts. [Online] www.eyeoneducation.com/ 